\title{
Business and Bludgeon at the Border: A transnational political economy of human displacement in Thailand and Burma
}

\author{
Jennifer Hyndman \\ Department of Geography, Simon Fraser University, 8888 University Dr., Burnaby, BC, Canada
}

Key words: asylum, Burma, refugees, Thailand, transnational corporation

\begin{abstract}
Transnational economic integration between Thailand and Burma is intimately linked to protection for Burmese refugees in Thailand. In the case of Burmese nationals who seek safety in Thailand, their protection becomes more negotiable as economic integration with Thailand proceeds. Since 1988, hundreds of thousands of Burmese citizens have fled beyond the borders of their state, fearing both human rights abuses and successive offensives by a military junta intent on its own survival. Critical analysis of the dynamic of human displacement and bi-national economic cooperation between the governments of Thailand Burma grounds this study. The story is one of transnational trade across one border, where people's labour, homes, and passports are exchanged - in an obscured fashion - for investment, natural resources, and economic cooperation. The Thai-Burmese border proves to be a flexible concept that can be invoked to produce refugees or blurred to promote binational economic infrastructure and trade. Despite economic booms and busts in Southeast Asia, economic integration in the region is on-going. At the same time, Burma's government - the State Peace and Development Council - and its military force more and more citizens into neighbouring countries. Their reception in Thailand, however, is increasingly chilly.
\end{abstract}

\section{Introduction}

The story told here is of transnational trade across one border, where people's labour, homes, and passports are exchanged - in an obscured fashion - for investment, resources, and economic cooperation. The ensuing geographical analysis traces links between economic integration across international borders and protection for persons who are displaced by fear of persecution, forced labour, or forced relocation. For more than fourteen years, hundreds of thousands of Burmese nationals have been displaced from their homes (US Committee for Refugees, 2001). The majority of these are displaced within Burma (also known as Myanmar ${ }^{1}$ ). Others have found temporary refuge in countries such as Thailand, India, and Bangladesh, while a fortunate few have been permanently resettled elsewhere.

Despite the ongoing and well-documented atrocities committed by the governing body of Burma, there has been remarkably little progress in resolving the plight of Burmese refugees in Thailand, a country that hosted countless Indochinese refugees during the aftermath of the Vietnam War (Falla, 1991). Burma's military-led government, the State Peace and Development Council (SPDC), formerly known as the State Law and Order Restoration Council (SLORC), has grown to rely on Thailand, both as a market for its natural resources and as a source of investment in Burma's historically closed economy (Rodman, 1998). This paper makes the argument that as transnational economic inte- gration increases between Thailand and Burma, and within the region of Southeast Asia as a whole, the protection of Burmese refugees in Thailand becomes more negotiable. A study of the relationship between the forced migration of Burmese and bi-national economic cooperation between the governments in Thailand and Burma grounds this approach. Transnational investment across the Thai-Burma frontier is juxtaposed with the international displacement of people across this same border in an effort to elucidate the relationship between political economy, human rights, and protection for Burmese affected by forced migration.

The paper addresses the ways in which intergovernmental economic cooperation generates, at one scale, a functionally integrated transnational economy that, in turn, challenges the meaning and importance of political borders between nation-states. The meaning and value of migrants who cross these borders has also changed. More specifically, displaced Burmese seeking asylum and safety in a neigbouring country are increasingly part of a regionalized economic zone that does not necessarily recognize their plight and status as refugees. Instead, there is a transnational trade (off) in which human rights and asylum are exchanged for lucrative access to natural gas and other natural resources. This geography of displacement is circumscribed by a transnational political economy within the region. 


\section{A note on method and approach}

The research for this paper stems from a larger project that examines the transnational social, political, and economic ties that Burmese refugees who have resettled in Canada maintain with their family, friends, and allies living elsewhere (Hyndman and Walton-Roberts, 2000). The Vancouver-based research documents the on-going and intense personal and political transnational ties that Burmese refugees, now landed immigrants living in Canada, maintain with displaced friends and family still living in Thailand. Prior to the 50 interviews that provided the basis of this research, but after a year of meetings and community involvement with members of the Burmese diaspora in Vancouver, Canada, I made a field visit in October 1996 to the Mae Hong Son Province in Northern Thailand. Through the Vancouver connections, meetings with members of the All Burma Students Democratic Front (ABSDF) were organized in Mae Hong Son town, the provincial capital. Subsequent to these meetings, I accompanied one ABSDF member to a camp to meet with other student and former rebel leaders. The accompanying ABSDF member served as translator during five of six meetings held in the camp, including student leaders, water and sanitation workers, creche staff, and school teachers. 'Sonny', one of the former rebel leaders with whom I met, spoke good English. ${ }^{2} \mathrm{He}$ was one among many in the camp who had recently surrendered arms to become a refugee in Thailand.

Separate contact in Mae Hong Son town was also made with international non-governmental organizations, in particular the International Rescue Committee (IRC), and with a leader of the Karenni - the major ethnic group displaced across this segment of the Thai-Burma border. Interviews were held with IRC team leader and her several of her staff, and - through IRC - with the Karenni leader who asked not be named. This field visit was both a departure point for research with members of the Burmese diaspora in Vancouver, and the basis of a more regional analysis of the dynamics of forced migration in Southeast Asia. The links between displacement, political economy, and cross-border integration in the region emerged as a key consideration of a transnational analysis.

\section{Forced migration from Burma}

Evidence of Burma's bi-national links with Thailand and its regional economic integration is more recent than resistance to and protests against the Government of Burma. Since 1948, the year of Burma's independence from Britain, a number of ethnic minorities have fought to win autonomy and recognition from the government in Rangoon. Unfulfilled promises and other legacies of colonialism have fuelled ethnic unrest and conflict today (Falla, 1991; Human Rights Watch, 1992). In 1962, a military coup led by General Ne Win replaced the short-lived, democratically elected, post-independence government. ${ }^{4}$ Burma has been governed by successive military regimes since that time. By 1974, at which time a new constitution gave birth to the Socialist Republic of the Union of Burma, nearly all of the ethnic minority groups of the country had formed armed resistance fronts (Aung San Suu Kyi, 1997). Those whose members have sought refuge in Thailand at one time or another include the Karen, San, Karenni (Kayah) and the Mon.

On August 8, 1988, unarmed students and civilians took to the streets of Rangoon to protest the repression of the military government. Thousands were shot dead by military forces. On September 18, 1988, the military government struck back, and days of horrific violence against unarmed civilians ensued. Thousands more were murdered, including peaceful demonstrators and school children. Many more fled the nation's capital to join historically marginalized ethnic minorities living in border regions (Lintner, 1990; Martin, 1991). The government imprisoned political foe and active member of the National League of Democracy (NLD), Aung San Suu Kyi, in 1989. A powerful symbol of opposition, Aung San Suu Kyi's father, Aung San, was the assassinated leader of Burma's independence movement. In May 1990, the NLD in Burma won an overwhelming majority in the parliamentary election, taking 392 of 485 contested seats. However, the military rulers (the then self-declared State Law and Order Restoration Council) who lost the election never allowed the NLD to take office and arrested many of its members. They continue to govern today. Despite the formal release of Aung San Suu Kyi from house arrest in July 1995, her movements remain carefully monitored and activities restricted by the SPDC.

The use of forced labour by the military government has been well documented (US Committee for Refugees, 1996; Aung San Suu Kyi, 1995; New Internationalist, 1996). UN rapporteur, Justice Rajsmoor Lallah, has noted in a series of reports that Burma's military had forcibly relocated and essentially detained or forced into labour more than one million people without compensation (Agence France Presse, March 30, 1997; US Committee for Refugees, 1999). The International Labour Organization (ILO) echoes these findings, citing evidence that the military has imposed forced labour on civilians for portering, construction, maintenance and servicing of military camps. Burmese citizens, particularly those of minority status, are recruited under threat as porters who carry food and materials to supply government troops. Adults and children are unpaid for their work and poorly treated. Women have been taken as prostitutes by government soldiers, while others have been sold into the same trade on the Thai side of the border. The construction of railway lines (Ye-Tavoy), airport facilities, and other tourist infrastructure by modern migrant slaves for what was declared in 1996 as 'Year of the Visitor' is cruelly ironic. Curious tourists were encouraged to bring their precious foreign currency and witness the new face of 'Myanmar' (the name given to Burma by the SLORC [State Law and Order Restoration Council] government after 1988) constructed in large part on the backs of dislocated Burmese. To strengthen order in the capital, 'Yangoon', the government makes ongoing attempts to 'Burmanize' the city (US Committee for Refugees, 1999). Groups who are not ethnic Burmans have 


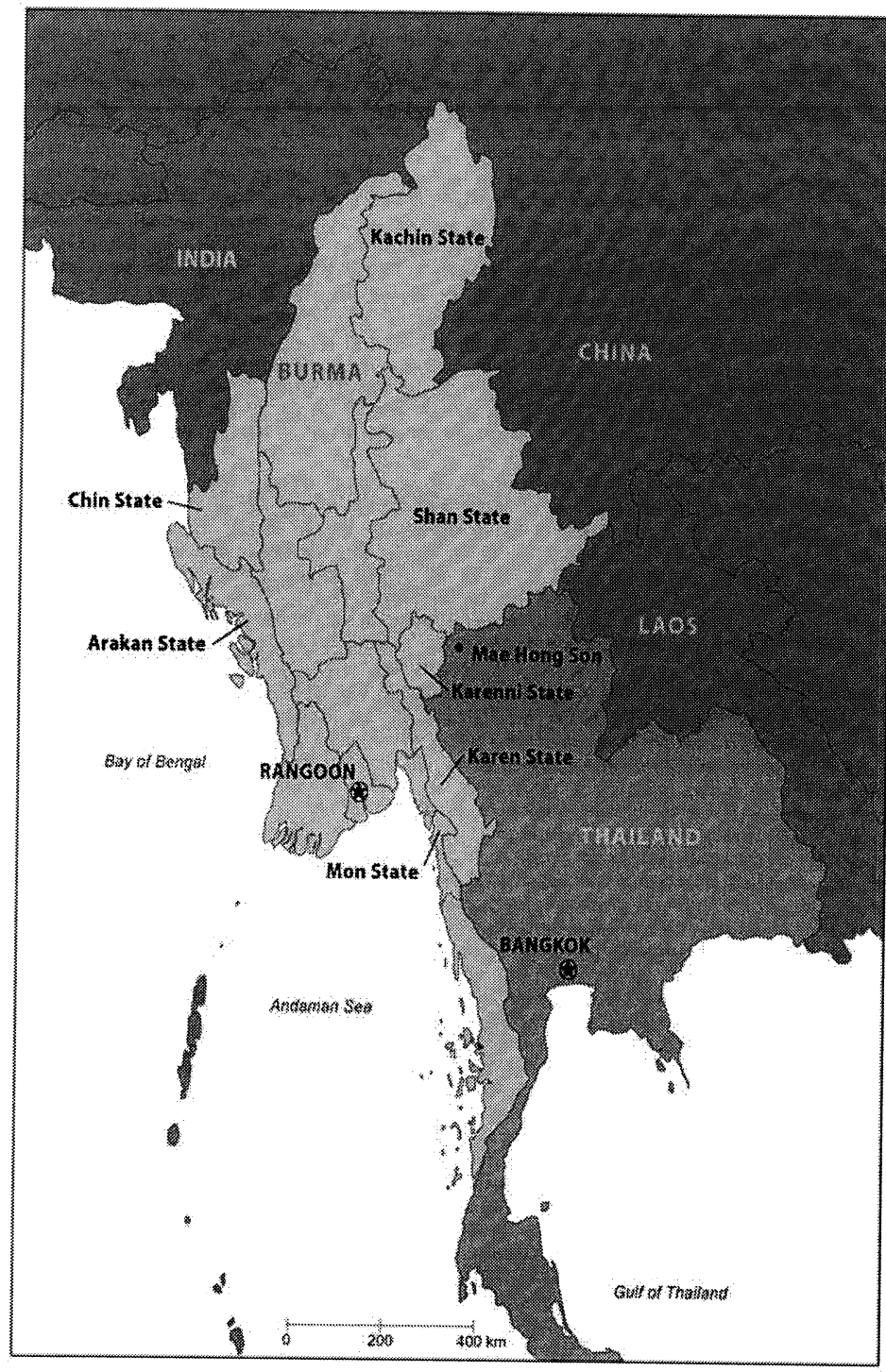

Figure 1. Map of the Burma-Thailand border zone (courtesy, John Ng).

been forcibly relocated to ill-equipped villages in outlying areas. In December 1998, the UN General Assembly issued another resolution condemning human rights violations in Burma (US Committee for Refugees, 1999).

SLORC (now SPDC) almost doubled the size of its military, both in term of troops and arms between 1988 and 1993. The number of soldiers grew from 180,000 to 340,000 , and China sold the government new weapons, including jet fighters, tanks, and naval patrol boats, in a $\$ 1.2$ billion deal From 1992 onwards, tens of thousands of ethnic minority villagers in Burma along its 2,400 kilometre border with Thailand were forced to relocate to army-controlled towns, as they ceded control of territory, trade routes, and timber resources to SLORC (Human Rights Watch, 1998). In 1996, the Burmese government launched a major civilian relocation program in the Karenni and Shan States in the Eastern part of the country. Some 300,000 Shan and 20,000
Karenni were forced from their villages into designated relocation sites guarded by the military (Amnesty International, 1999a).

Within Burma's borders, a geography of displacement is on-going. Many Burmese have resisted SPDC's efforts to force their relocation and labour by moving to border areas where ethnic minorities have prevailed or by leaving the country. Of Burma's 46 million people, between 600,000 and 1,000,000 were internally displaced in 2000 (US Committee for Refugees, 2001). The total number of Burmese refugees officially recognized by the United Nations High Commissioner for Refugees (UNHCR) in Thailand has risen from 140,000 in 1997 to 216,000 at the end of $2000 .^{5}$ The US Committee for Refugees also estimates that another 350,000 people live in refugee-like circumstances, but without official status (US Committee for Refugees, 1998; 
US Committee for Refugees, 1999; US Committee for Refugees, 2001).

\section{Narrowing paths to asylum}

Burmese citizens opposed to their government and military's undemocratic practices began fleeing to Thailand in the 1980s. From camps on the Thai side of the border, those seeking official status as refugees made their way to Bangkok, the only location in which the Government of Thailand permitted the United Nations High Commissioner for Refugees (UNHCR) to operate. Until 1990, UNHCR required asylum seekers to sign an agreement to abide by Thai law and UNHCR principles as documented evidence of their registration with UNHCR. After that time, when two Burmese registered with UNHCR hijacked a Thai Airways plane in 1990, however, this practice was stopped. UNHCR does not confer Convention refugee status on these applicants because Thailand is not a signatory to the 1951 Convention Relating to the Status of Refugees. Thailand has been, however, a member of the Executive Committee of UNHCR since 1979. It has obligations under customary law that include the non-refoulement of refugees (Human Rights Watch, 1998).

More recently, UNHCR has granted 'person of concern' status to asylum seekers who made the trip to Bangkok. Many such persons were required to stay in the 'safe area' in Ratchaburi, west of Bangkok. The 'safe area' was, however, closed to new arrivals in 1996 by Thai authorities, leaving some 3,000 persons registered with UNHCR stranded in the capital, at risk of being arrested and/or deported as illegal immigrants. In June 1997, the Thai army began implementing a new policy whereby it closed the border to all new arrivals, thus denying asylum to those fleeing Burma (Human Rights Watch, 1998).

If Thailand learned one lesson from its experience hosting Indochinese refugees it was to avoid internationalizing a refugee crisis at all costs. The Thai authorities perceived UNHCR assistance as a magnet, drawing more and more people into Thailand (Human Rights Watch, 1998). Furthermore, the recognition of refugees from neighbouring countries would prove problematic when securing economic cooperation and trade deals with the governments of countries from which refugees fled.

\section{Economic Integration between Thailand and Burma}

A generally benign laissez faire attitude toward the camps on the part of Thai authorities that was in effect from 1984 shifted to a much more hard-line stance around 1992, as relations between Rangoon and Bangkok warmed and Thai investors saw increasing economic opportunities in Burma (Human Rights Watch, 1998). Since that time, political and economic relations have waxed and waned. Economic links between Thailand and Burma are numerous and deserve a comprehensive discussion precluded here. Nonetheless, some major contours of transnational economic relations should be outlined.
Trade in narcotics, heroin in particular, is notorious, and increased dramatically when SLORC took office in the late 1980s. Estimates suggest that Burma provides some $60 \%$ of the heroin consumed in North America alone, and that increased production in Burma since 1989 has resulted in increased availability in, for example, New York City (Bernstein and Kean, 1996). At a more local level, the level of addiction among Burmese is high, specifically among miners who are often offered their salary in hard drugs rather than cash. The UN reports that $60-70 \%$ of intravenous drug users in Burma are HIV positive, a chilling figure considering that ' $[\mathrm{m}]$ illions of migrants are pouring out of Burma into neighboring Thailand, China and India, carrying HIV with them' (Bernstein and Kean, 1996, p. 16). The immense drug trade, much of which finances Burma's government, has both economic and social implications for adjacent countries. Much like the large-scale trafficking of women from Burma to Thailand (Skrobanek et al., 1997), the drug trade is both part and parcel of economic integration.

Narcotics production in Burma has been affected by eradication efforts by authorities in other Asian countries, notably Afghanistan. A Taliban decree to stop poppy production in that country saw Burma become the single largest source of opium production in 2001 (UN ECOSOC, 2001, p. 5). Thai authorities went on record as being 'very nervous' about the implications of the Taliban ban, given that hundreds of millions of methamphetamine pills already pour across its frontier with Burma (The Straits Times, 2001). US satellite imagery reveals that Burma has about 108,000 hectares of poppy fields, from which comes the majority of Southeast Asia's heroin. In 2001, Burma respresented 68\% of the total volume of opium produced worldwide compared to $23 \%$ for Afghanistan. In 2000, the figures were almost exactly the reverse (Agence France Presse, 2002).

The presence of migrant workers from Burma in Thailand is another indication of economic integration. By July 1997, Thailand's economy began showing signs of the 'Asian flu' that resulted in mass unemployment amid a more endemic economic crisis. A new government policy aimed at freeing up as many jobs for Thai nationals as possible was developed, and by January 1998, the government announced its intention to deport Thailand's entire foreign 'illegal immigrant' workforce. Roundups and deportations in the Mae Sot area, where a number of refugee camps are located, occurred during that same month. Before the Asian flu set in, Thailand had hosted more than one million undocumented migrant workers, of whom approximately $75 \%$ are Burmese (Bernstein and Kean, 1996). Not all undocumented Burmese workers refugees are refugees, nor are all refugees undocumented Burmese migrant workers, but it is significant for geographers that the government crackdown would begin near refugee camps. Since November 1999, the Thai Government has been deporting Burmese migrant workers, some of whom are viewed as potential asylum seekers (Amnesty International, 1999b).

The sizeable number of migrant workers is a clear expression of one way the economies of Thailand and Burma are functionally integrated. Disparities between the two 
countries are acute. While geographically similar in size, Thailand is more densely populated with 57 million inhabitants compared to Burma's 46 million. Though they share a prevailing religious orientation to Theravada Buddhism, Burma is more culturally diverse. ${ }^{6}$ Politically and economically speaking, the two countries could not have more different histories: Thailand has developed into a largely freemarket, and somewhat democratic state, whereas Burma has been a highly centralized state and closed economy since General Ne Win took power in 1962 (Smith, 1991). This latter isolationist approach shifted considerably after 1988 when the government changed its name to SLORC and announced reforms that would render the economy increasingly open to foreign investment (Human Rights Watch, 1998).

On December 14, 1988, General Chavalit Yongchaiyudh, Thailand's commander-in-chief of the army and foreign minister at the time was the first foreign leader to meet with the new government. The purpose of his trip centred upon securing lucrative timber and fishing deals for Thai companies in Burma. For a period of several years, Thailand was able to maintain a precarious and ambiguous policy of meeting its international refugee obligations and forging closer economic links with Rangoon(Human Rights Watch, 1998). The 'Thai-Burma Joint Commission' was formed in January 1993. From this year on, Thailand promoted Burma's prospective membership in the Association of Southeast Asian Nations (ASEAN). In July 1997, on-going lobbying by several ASEAN members ensured Burma's admission to the group. However, as economic integration proceeded, the protection of Burmese nationals fleeing to Thailand became more fickle.

The physical and economic infrastructure across the Thai-Burma border has grown significantly over the past decade. A bridge across the Moei River, which delineates part of the Thai-Burma border, however, remains unfinished. The bridge has economic value as a potential short-cut from Bangkok to Rangoon. It has strategic value as a means of eventually returning refugees from Thailand to Burma. It also has official significance as a 'friendship' bridge which signals the cooperative (and lucrative) relationship that has been forged between the Burmese and Thai governments. The bridge is based on the desire of both countries to bring prosperity to the area (Reuters, 1997). The 'friendship bridge' opens up the unsettling possibility of returning displaced refugees without status in Thailand to the country from which they initially fled. A superhighway that would link Thai and Burmese coasts, running west of Bangkok, has also been planned, ostensibly to allow Thailand's huge tourist population easy access to a country that has isolated itself since a military coup in 1962. Significant Thai and other Southeast Asian investment in the nascent hotel industry in Burma is not unrelated to this cooperative cross-border venture.

While eager to maintain favour with the international community for its refugee record, the Government of Thailand has proven at least as interested in the bi-national economy and, in particular, in the building of the natural gas pipeline between Burma and Thailand as it is in refugee relations. The border this pipeline crosses is the same frontier where ethnic minorities rebel groups, such as the Karen and Karenni, have historically fought to resist government troops and control their own territory since Burma's independence. One way to secure these territories for resource extraction has been to sign individual cease-fires with rebel fronts. Between September 1989, when the Shan State Army signed an agreement, until June 1995, when the New Mon State Army announced their cease-fire, a total of fourteen ethnic minority armies had entered into peace deals with the SLORC (Human Rights Watch, 1998). By July 1998, the only groups not to sign with the Burmese authorities were the Karen National Union (KNU), various Shan groups, and the Rohingya Solidarity Organization. As the cease-fires were signed and the level of fighting decreased, the Thai authorities adopted the position that ethnic minority refugees had nothing to fear by returning home. Instances of refoulement were noted, as they took a tougher stance against Burmese refugees, despite the documented abuse of human rights in Burma.

Bilateral trade and Burma-Thai relations improved through from 1989 to 1994. As of August 1994, Thailand had been the largest ASEAN investor in Burma, with projects valued at $\$ 211.14$ million. Thai investment declined somewhat in 1995 when the Burmese Government accused Thailand of harbouring dissidents and members of recalcitrant minority groups that would not sign cease-fires. By 1997, however, relations had mended between the two countries, and the Thai Government appeared anxious to clear out refugees from the border areas where the joint infrastructure projects were planned with its Burma partner (Agence France Presse, March 30, 1997).

\section{Production versus protection and human rights}

Cross-border exchange and economic cooperation between the governments of Thailand and Burma, in conjunction with various multinational companies, is linked to the dispersion of the Burmese population, both within and beyond the borders of Burma. This set of recursive processes is predicated on (1) increasing cross-border trade and shared infrastructure between Thailand and Burma; and (2) related army offensives on the Burma side of the border to eliminate rebel groups, whose land is essential to the major infrastructure project and whose 'cooperation' is necessary to secure investment.

Multinational investment in Burma has been considerable, particularly in the oil sector. In the early 1990s, the military government in Burma opened up its natural resources to foreign development. The US company, UNOCAL, and the French Total struck a controversial \$1.2 billion deal with Thai and Burmese state energy companies to construct a 260 mile pipeline from Burma to Thailand and to develop offshore natural gas fields (Rodman, 1998). Human rights organizations under the umbrella of the Free Burma Campaign - a transnational coalition of human rights and environmental organizations - hold the companies responsible for the use of forced labor in the construction of infrastructure, ecological damage, and the forced relocation 
of villages to clear territory for the pipeline (Rodman, 1998, p. 32). UNOCAL and Total maintain that the alleged violations are unrelated to their investment; they assert their right to continue working regardless of the political practices of the host country.

Other transnational companies have bowed to pressure from activist groups that concentrate their efforts on boycotts in the countries where products are marketed. County, state, and local ordinances, for example, which threaten to withdraw purchasing contracts from specific companies that have investments in Burma have been most effective. Selective purchasing laws bar companies doing business in Burma from receiving local contracts. Such laws are legal as long as they do not contradict or impinge upon the jurisdiction of federal government policy and legislation. Apple Computer and Motorola, for example, ended their relationship with Burmese distributors in order to maintain supply contracts with Massachusetts and San Francisco. But as Rodman (1998, p. 33) points out, [n]onstate pressures have been most successful when an MNC's [multinational corporation's] vulnerability in its home market is disproportionate to its stake in Burma. Thus, withdrawal from Burma was a more viable business decision for Pepsico, whose home market was at risk of being excluded from an increasing number of college campuses, than for oil companies, which have been subject to less scrutiny by citizen groups and non-governmental organizations. ${ }^{7}$

European and North American governments have also taken stands against the policies of the military government in Burma. US Congress passed a sanctions bill in 1996 that precluded new investment in Burma; the administration invoked the bill in April 1997. The Canadian Government followed suit in August 1997 with limited sanctions against Burma (Manthorpe, 1997; Sallot, 1997), just after the Association of Southeast Asian Nations (ASEAN) admitted Burma to its membership. European Union sanctions have been limited to arms sales, nonhumanitarian aid, and trade preferences. Combined with the extensive campaign for human rights sanctions by nongovernmental actors, these efforts have contributed to Burma's appellation as the 'South Africa' of the 1990s' (Rodman, 1998).

ASEAN countries that lobbied for Burma's inclusion in the group claimed that such a move would encourage the SPDC to improve its human rights record through a policy of constructive engagement. According to Amnesty International (1999a), the opposite has been true. The government has intensified its repression of the opposition party, the National League of Democracy, and increased forcible relocation programs. Forced labour among all seven ethnic minority states continues at a significant level (Human Rights Watch, 2001).

As Bangkok's relations with Rangoon have warmed and sometimes cooled over the past few years, refugee reception of Burmese asylum-seekers in Thailand has become less hospitable. The old adage of trade versus aid takes on a new meaning, as trade interests conflict with humanitarian need and aid. While the Thai Government has finally allowed the United Nations High Commissioner for Refugees (UN-
HCR) permission to establish a permanent presence to assist refugees, it still restricts UNHCR's activities. The Karen Refugee Committee has urged the Thai Government to allow UNHCR to provide aid and assistance to refugees seeking shelter along the border following the SPDC's military onslaught, beginning early in 1997 (Reuters, 1997). The Thai response has been to accuse the Karen National Union of trying to make its fight with Burma an international issue that would draw attention and perhaps intervention from the outside world when Thailand considered the matter a Burmese internal affair. According to Thai officials, if UNHCR were allowed to adminster the Thai camps for Burmese refugees along the border, this would 'complicate' the border situation and might cause some 'misunderstanding' with Burma. Humanitarian intervention could be harmful to Thai trade and cooperation with Burma. Likewise, Burma views $\mathrm{UN}$-sponsored investigations of human rights a blatant attempt to interfere with its internal affairs (US Committee for Refugees, 1999). The suggestion that refugees in Thailand are the internal affairs of Burma represents the domestication of violence and subsequent human displacement not only on a national scale, but within the bi-national economy of Burma and Thailand.

Transnational trade liberalization and cooperation comes to this Southeast Asian region at considerable human cost for those marked by the 'wrong' or 'other' ethnic, social, and political locations. Within the bi-national economy of Thailand and Burma, the displacement of Burmese refugees is at once domesticated and effaced. Political protest and related displacement are dismissed as internal state matters. Land and labour are treated as state resources subject to the military government's objectives. Despite the obscured transnational trade in resources and displacement of 'undesirables', the SPDC mobilizes the language of sovereignty in its defense when other transnational actors look on and criticize its actions. The Government of Thailand is ambiguous in its actions but complicit in the effort to localize the refugee issue.

\section{Reconciling refugees and revenues}

The geographical disjuncture between refugees whose identity is inscribed by international borders and an integrated transnational bi-national or regional economy that aims to blur such borders presents a dilemma. How, in the context of lucrative transnational timber, fishing, and natural gas deals, can the rights of Burmese refugees be protected if the rights of Burmese nationals cannot? There is a spatial mismatch between refugees, who are product of the statebased international refugee regime, and revenues that are generated through multinational investment. Talk of promoting international trade and economic integration populate academic, governmental, and corporate domains, without much attention to standards or safeguards that might protect people affected by these supra-national constellations of power. There are no 'ethics of encounter' (Shapiro, 1996) to mediate the variegated politics and processes of regional economic integration and human dislocation. 
One might contend that the state-based rules and customary law of the international refugee regime are outdated, that human rights instruments are unenforceable, and furthermore that neither human rights instrumentation nor the refugee regime is applicable to issues generated by multinational investment. But the fact remains that people's freedoms and rights are protected by national governments. In the absence of such protection, refugees must rely on human rights instruments and the norms of the state-based refugee regime, until some other alternative is developed. Hannah Arendt (1958) warns that universal rights fall prey to such divides and that protection is imperiled in the absence of a nation-state. Writing during the aftermath of the Second World War, she maintains that the rights of citizens as nationals are far more important that those accorded as human rights on a global scale precisely because they are both applicable and enforceable. While non-state actors, such as city councils or consumer advocacy groups, show some proven results and offer directions for positive change, their support is leveraged on the basis of these same human rights instruments and the SPDC's violation of them. The Free Burma Campaign, for example, is an inspiring model of transnational coalition-building and effective lobbying, yet it has to operate outside of the national context that renders states responsible for the protection of their citizens and assurance of their rights.

The blurring of borders at once opens up new possibilities, but also poses new dangers. A call has been made to trace the 'transnational imaginary' - the as-yet-unfigured horizon of contemporary cultural production by which national space/identities of political allegiance and economic regulation are being undone and imagined communities of modernity are being reshaped at the macropolitical (global) and micropolitical (cultural) levels of everyday existence (Wilson and Dissanayake, 1996, p. 6). Currently, the conventions and agreements among nation-states are the only codes of conduct for identifying and possibly intervening in the affairs of governments, corporations, and other bodies, despite the historical and geographical mismatch they embody. Until alternate and more equitable ways of moving between cultures and economies are developed, these international instruments constitute the only, albeit blunt, available intervention and the major basis for positive change in the face of violence, abuse, and displacement.

The movement of bodies across borders is intimately related to trade in other goods. The geography of displacement outlined here calls for a new way of approaching politics. Political action, or ( $p$ )raxis is not prohibited by a politics of not belonging... it is important to disrupt the homelabroad and the margin/center constructs for more complex positionings (Grewal, 1994, p. 234-35). Ironically, it is the politics of belonging - based on beliefs in common origins - that decisively include and exclude certain groups of people, giving rise to possibilities of political mobilization, on the one hand, and the tragic potential of ethnic cleansing, rape, and war, on the other (Ignatieff, 1993; Watts, 1996). These politics of (not) belonging have shaped the forced migration of ethnic minorities and dissidents in and beyond the borders of Burma.

As long as the governments of Thailand and Burma continue to cooperate in economic terms through trade liberalization and investment, and the SPDC maintains 'order' at the border to secure the flows of Burmese resources, a transnational political economy of human rights, or trade in bodies for goods, will continue. The border is 'open for business' in every sense of the word. As refugees flee, natural gas will flow south, from Burma into Thailand. These transnational politics generate corporeal, cross-border movements of refugees, though these people are no longer recognized as such by Thai authorities. As both Canada and the US agree to resettle some of the displaced Burmese selected from the so-called 'safe camp' outside Bangkok, the Burmese diaspora in these countries and others grows and with it political struggles against the forces that led to its migration.

\section{Endnotes}

${ }^{1}$ Myanmar is the name given to Burma by the military junta of the State Law and Order Restoration Council (SLORC), recently renamed the State Peace and Development Council (SPDC). Accordingly, many people choose to refer to the country by its pre-SLORC moniker, Burma.

${ }^{2}$ Sonny was also interviewed by Amitav Ghosh (1996) earlier that year.

${ }^{3}$ There are seven ethnic minority states in Burma, along with several additional 'divisions'. For the purposes of this paper, only the ethnic minority states are of relevance and are therefore shown on the map. Burmans are the transparent identity category; this ethnic group is the most represented among government officials.

${ }^{4}$ This day is best known by the shorthand ' $8 / 8 / 88$ ' to protestors and those opposed to the military regime.

${ }^{5}$ UNHCR determines refugee eligibility based on criteria outlined in the 1951 Convention Relating to the Status of Refugees. During 2000, however, Thai officials became increasingly impatient with refugee flows from Burma. The Thai Government's criteria for admitting new refugees remained restricted to 'persons fleeing conflict'. Thailand did not consider as refugees people who were fleeing human rights abuses (US Committee for Refugees, 2001: 129).

${ }^{6}$ The social health of Thailand is impressive compared to that of Burma, and may also provide clues about migrant movement. Female life expectancy in Burma is 59.3 years compared to 70.2 years in Thailand; for men, the contrast is similar: 56 years and 66.4 years respectively. Infant mortality provides another clue. Whereas Thailand has 32 deaths per thousand babies born in 1995, Burma has 90 . Illiteracy at $16.9 \%$ in Burma is almost three times that of Thailand (United Nations, 1997).

${ }^{7}$ The constitutionality of such state and local enactments has been hotly debated. See Schmahmann and Finch (1997) for a discussion of the legal arguments pertaining to US-Burma relations. 


\section{References}

Agence France Presse, (AUTHOR YEAR?): "UN says opium supply could shift from Afghanistan to Myanmar", (from Lexis/Nexis database) January 28.

Agence France Presse, 1997: from Lexis/Nexis database, March 30. No title.

Amnesty International, 1999a: 'Myanmar: Military keeps ethnic minorities 'like chickens in a basket', news release issued by the International Secretariat of Amnesty International, June 30.

Amnesty International, 1999b: "Kingdom of Thailand: Thousands of migrant workers from Myanmar", AI Index: ASA 39/04/99; UA 295/99 (Ill-treatment and possible forcible return of asylum seekers), Amnesty release November 10 .

Arendt H., 1958: The Origins of Totalitarianism. Meridian, Cleveland/New York.

Aung San Suu Kyi, 1997: The Voice of Hope. Penguin, New York.

Aung San Suu Kyi, 1995: Freedom From Fear. Penguin, London.

Bangkok Post, March 23, 1997 (from Lexis/Nexis global news database). No title.

Bernstein D. and Kean L., 1996: People of the Opiate. The Nation 16: 1118.

BurmaNet News, 1996: Burmese Prostitutes Trapped in Dark Underworld, Issue \#327, Jan. 21.

Falla J., 1991: True Love and Bartholomew: rebels on the Burmese border Cambridge University Press, Cambridge (England)/New York.

Ghosh A., 1996: A Reporter at Large - Burma. New Yorker 12: 38-55.

Grewal I., 1994: Autobiographical Subjects, Diasporic Locations. In: Grewal I. and Kaplan C. (eds), Scattered Hegemonies: Postmodernity and Transnational Feminist Practices, pp. 231-254. University of Minnesota Press, Minneapolis.

Human Rights Watch, 2001: 'World Report 2001', section on Burma, http://www.hrw.org/wr2k1/asia/burma.html (accessed March 4, 2002).

Human Rights Watch, 1998: 'Unwanted and Unprotected: Burmese Refugees in Thailand', published booklet, vol. 10, no. 6, September.

Human Rights Watch, 1992: Abuses against Burmese refugees in Thailand, Asia Watch, New York, March 20.

Hyndman J. and Walton-Roberts M., 2000: Interrogating Borders: A Transnational Approach to Refugee Research in Vancouver. The Canadian Geographer 44(3): 244-258.

Ignatieff M., 1993: Blood and Belonging: Journeys into the New Nationalism. Farrar, Straus and Giroux, New York.

Lintner B., 1990: Outrage: Burma's Struggle for Democracy. White Lotus, London and Bangkok.
Manthorpe J., 1997: Canada weighs trade curbs as Burma drags feet on reform. Vancouver Sun, July 28.

New Internationalist collective, 1996: Burma: a cry for Freedom, New Internationalist, no. 280 , June.

Reuters, 1997: Bangkok Post, March 13 (no title; Lexis-nexis database).

Rodman K.A., 1998: Think Globally, Punish Locally: Nonstate Actors, Multinational Corporations, and Human Rights Sanctions. Ethics and International Affairs 12: 19-41.

Sallot J., 1997: Canada puts trade restrictions on Burma, The Globe and Mail, August 8.

Schmahmann D. and Finch J., 1997: 'The Unconstitutionality of State and Local Enactments in the United States Restricting Business Ties with Burma (Myanmar). Vanderbilt J. Transnational Law 30(2): 175-207.

Skrobanek S., Boonpakdee N. and Jantateero C., 1997: The traffic in women: human realities of the international sex trade. Zed Books Ltd., London/New York.

Smith M., 1991: Burma: Insurgency and the Politics of Ethnicity. Zed Book, London and New Jersey.

The Straits Times (Singapore), 2001: Bangkok edgy at Taleban's poppy ban, July 11.

United Nations Economic and Social Council, 2001: Follow up to the Action Plan on International Cooperation on the Eradication of Illicit Drug Crops and on Alternative Development, Report of the Executive Director of the Commission on Narcotic Drugs, 20 December.

United Nations Statistics Division, 1997: Infonation. United Nations Publications, New York.

US Committee for Refugees, 2001: World Refugee Survey 2001. Immigration and Refugee Service of America, Washington D.C.

US Committee for Refugees, 1999: World Refugee Survey 1999. Immigration and Refugee Service of America, Washington D.C.

US Committee for Refugees, 1998: World Refugee Survey 1998. Immigration and Refugee Service of America, Washington D.C.

US Committee for Refugees, 1996: World Refugee Survey 1996. Immigration and Refugee Service of America, Washington D.C.

Watts M., 1996: Mapping Identities: Place, Space, and Community in an African City. In: Yaeger P. (ed.) Geography of Identity, pp. 59-97. University of Michigan, Ann Arbor.

Wilson R. and Dissanayake W., 1996: Introduction: Tracking the Global/Local. In: Wilson R. and Dissanayake W. (eds), Global/Local: cultural production and transnational imaginary, pp. 1-18. Duke University Press, Durham. 